\title{
Redescription of the Male of Lachesilla yucateca Mockford (Psocodea: "Psocoptera": Lachesillidae) and the Northward Extension of the Species' Range ${ }^{1}$
}

\author{
Edward L. Mockford ${ }^{2}$ and Diane W. Young ${ }^{3}$
}

\begin{abstract}
Lachesilla yucateca Mockford, previously known from the Mexican states of Jalisco, Oaxaca, Quintana Roo, Tamaulipas, and Yucatán, is first recorded here from several localities in southeastern Texas. Females from Texas agree in all characters studied with the Mexican females. The single Mexican male had been damaged and was missing several critical structures when first described. We present a detailed description of the male based on Texas specimens. Some differences from the Mexican male are noted, suggesting the possibility that this male may represent a separate species. A gap of over $600 \mathrm{~km}$ exists between the northernmost Mexican and southernmost Texan collecting sites. We speculate about the nature of this gap.
\end{abstract}

Key Words: Psocoptera, Lachesillidae, new Texas record, northward range extension.

\section{Introduction}

The original description of Lachesilla yucateca Mockford (2002) was included in a paper in which the Lachesilla rena complex was defined and designated as a subdivision of the Lachesilla pedicularia species group (García Aldrete, 1974). Females of L. yucateca were recorded from the Mexican states of Oaxaca, Quintana Roo, Tamaulipas, and Yucatán. A single male was recorded from the UNAM Biological Station at Chamela, Jalisco. It was noted that the latter specimen was in very poor condition. On that account, only a very incomplete description of it could be made, but it clearly showed characters placing it in the Lachesilla rena complex. The proportions and markings of the forewing strongly suggested that it is the male of this species; nevertheless, because of its condition, it was not designated as a paratype.

Subsequent to the description of the species, L. yucateca has been found at several localities in southeastern Texas. Females from the Texas localities agree with the Mexican females in all specific characters studied, and no differences were found. The present paper presents a detailed description of the male based on Texas specimens and notes differences from the Mexican male. We also present here the Texas records, noting the northward extent of the known distribution of the species and speculating briefly about whether the gap between the southernmost Texas record and the northernmost Mexican record is real or a result of lack of collecting.

\footnotetext{
${ }^{1}$ Submitted on June 17, 2014 . Accepted on June 30, 2014. Last revisions received on July 8, 2014.

${ }^{2}$ School of Biological Sciences, Illinois State University, Normal, Illinois $61790-4120$ USA. Email: elmockf@ilstu.edu

3815 Thousand Oaks Loop, San Marcos, Texas 78666 - 7373 USA. E-mail: youngdw@centurytel.net
}

DOI: 10.9784/LEB2(2)Mockford.01

Electronically available on July 18, 2014. Mailed on July 16, 2014. 


\section{Methods}

The material consists of 14 males and 26 females from four Texas localities: Rockport (Aransas County), Palmetto State Park (Gonzales County), San Marcos (Hays County), and Welder Wildlife Reserve (San Patricio County). Specimens were taken primarily by sweeping grass, but also on dead leaves of a palmetto, Sabal minor (Jacq.) Pers. (Araceaeae or Palmae).

Procedures and abbreviations followed Mockford (2002). The head index, IO/d, is as defined and illustrated by Mockford (1989, Fig.1). A single male (D. Young No. 1371 - 1373, BugGuide image No. 524613), partially slide-mounted will be deposited in the collection of the Illinois Natural History Survey, Champaign, IL; all other specimens are deposited in the collections of DWY or ELM (see Material Examined, below).

\section{Systematic Entomology \\ Lachesilla yucateca Mockford \\ Figures 1-6}

Lachesilla yucateca Mockford, 2002: 158.

\section{Description of the male}

Diagnosis. With the characters of the Lachesilla rena species complex (Mockford, 2002). Forewings elongate and slender. Length/greatest width of forewing approximately 3.12. Forewing markings as noted below.

Color (in 80\% ethyl alcohol 2 months). Compound eyes dark gray. Rest of head beige; ocelli ringed in red; a light grayish-brown border of dorsal ecdysial line; postclypeus, clypeus, and labrum grayish brown. Antenna: scape, pedicel, and f1 dusky gray; remainder of flagellum black. Thorax beige, slightly darker brown on notal lobes. Legs beige, slightly darker on each t2. Forewings (Figure 1), hyaline, unmarked except for slight grayish-brown clouding at marginal end of each vein in distal half of wing, along vein R1 bordering pterostigma and very pale throughout the pterostigma. Preclunial abdominal segments nearly colorless, with faint gray transverse segmental bands dorsally. Clunium grayishbrown; epiproctal appendage dark brown.

Structural Characters. Forewing (Figure 1): R1 reaching wing margin at distal end of pterostigma slightly rounded; Rs-M junction ca. one-fourth length of preceding Rs segment. Hypandrium (Figure 2) with claspers short, straight, bluntly pointed; paraphallic pads (Figure 2, pp) large, ovoid. Phallic apodeme (Figure 2, pa) straight, relatively stout; phallic arms short, slightly curved. Epiproct (Figure 3, ep): process slightly swollen near tip, the tip acuminate, curved to right. Paraproct (Figure 3, par; Figure 4) with process long, beak-like, narrowing to truncate tip, lacking setula at tip; sensorium with $9-11$ trichobothria on basal rosettes and one peripheral trichobothrium lacking basal rosette. 

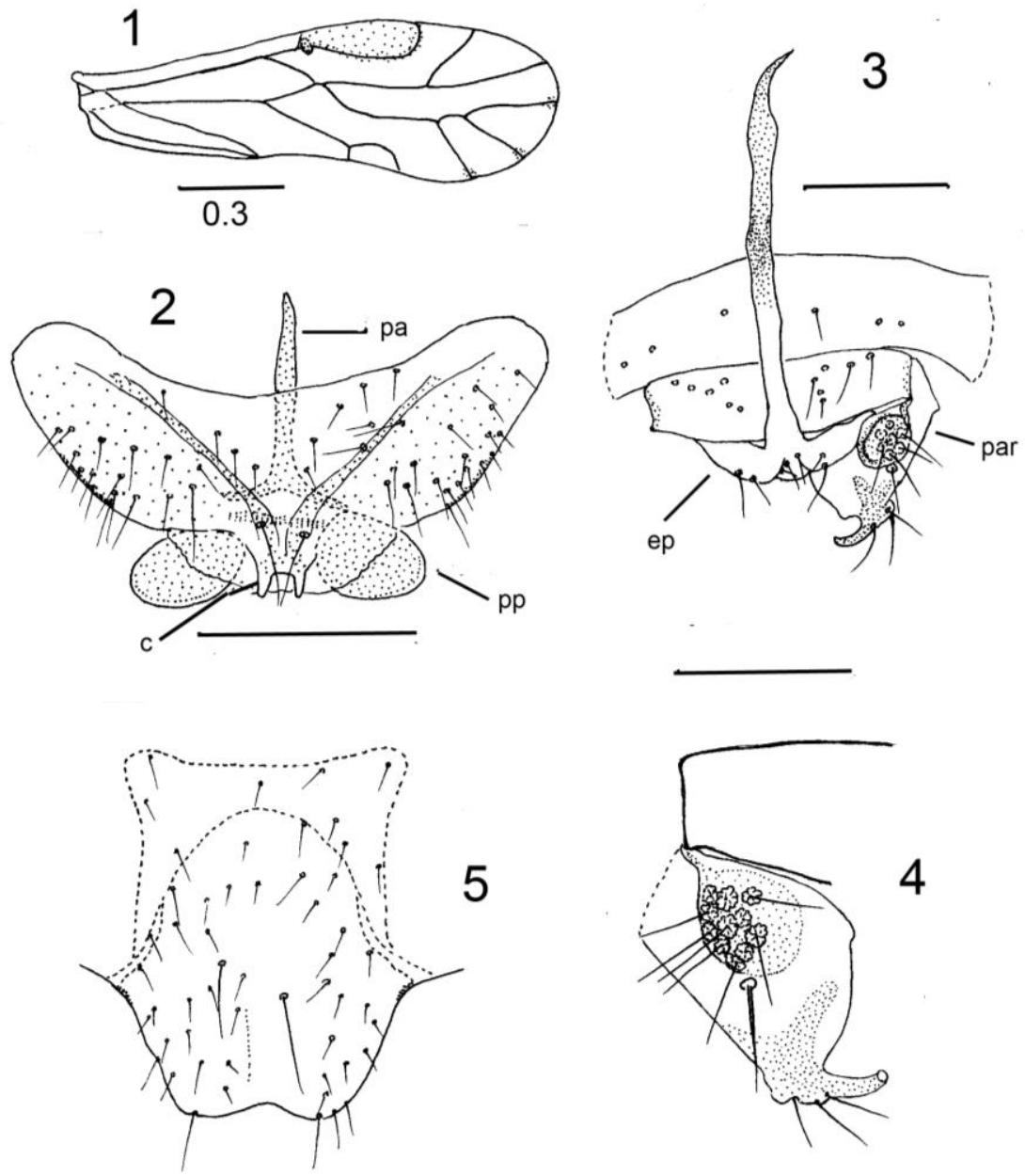

Figures 1 - 5. Lachesilla yucateca Mockford. 1. Male, forewing. 2. Male, hypandrium and phallosome $(\mathrm{c}=$ clasper; $\mathrm{pa}=$ phallic apodeme; $\mathrm{pp}=$ paraphallic $\mathrm{pad})$. 3 . Male, clunium, epiproct, and left paraproct. 4. Male, left paraproct and adjacent base of distoclunium. 5. Female, subgenital plate. Scale bars $=0.1 \mathrm{~mm}$ unless noted otherwise.

Male Measurements (in $\mu \mathrm{m}$, male from San Marcos, Hays Co., Texas). BL $=1100 ; \mathrm{FW}=1513 ; \mathrm{HW}=1129 ; \mathrm{F}=262 ; \mathrm{T}=464 ; \mathrm{t} 1=140 ; \mathrm{t} 2=81 ; \mathrm{t} 1 \mathrm{ct}=11$; $\mathrm{f} 1=163 ; \mathrm{f} 2=150 ; \mathrm{f} 3=139 ; \mathrm{IO}=248 ; \mathrm{d}=69 ; \mathrm{IO} / \mathrm{d}=3.59$.

Material Examined (all collected by and in the collection of DWY except as noted). Texas: Aransas Co.: Rockport, Connie Hagar Cottage Park, $28^{\circ} 03.0327^{\prime} \mathrm{N}, 9^{\circ} 02.677^{\prime} \mathrm{W}, 13$ April 2013, sweeping grass, 1 female; Gonzales Co.: Palmetto State Park, $2^{\circ} 38.6^{\prime}$ N, $97^{\circ} 35.17^{\prime} \mathrm{W}, 4$ October 2013, on 
dead leaves of Sabal minor, 1 female; same locality and habitat, 14 December 2013, 2 females, coll. ELM (ELM); Hays Co.: San Marcos; Thousand Oaks Loop, 29 $56.4^{\prime} \mathrm{N}, 9^{\circ} 55.23^{\prime} \mathrm{W}, 24$ July 2011, sweeping grass, 1 female; San Marcos: Aquarena Springs, 2953.6’N, 9755.8’W, 15 July 2011, 1 female; San Marcos: Nature Center, 2952.7’ N, 9755.9’ W, 10 - 11 January 2013, sweeping Panicum virgatum, 4 males, 8 females; San Patricio Co.: Welder Wildlife Reserve, $28^{\circ} 06.82^{\prime} \mathrm{N}, 97^{\circ} 25.10^{\prime} \mathrm{W}, 26$ April 2011, sweeping grass, 3 males, 2 females; $28^{\circ} 06.703^{\prime}-07.996^{\prime} \mathrm{N}, 9^{\circ} 25.029^{\prime}$ - 18.893'W, $10-11$ April 2013, sweeping grass, 5 males, 5 females; same locality, $28^{\circ} 06.703^{\prime} \mathrm{N}, 97^{\circ} 18.893^{\prime} \mathrm{W}$, 11 April 2013, 2 males, 4 females, coll. ELM (ELM).

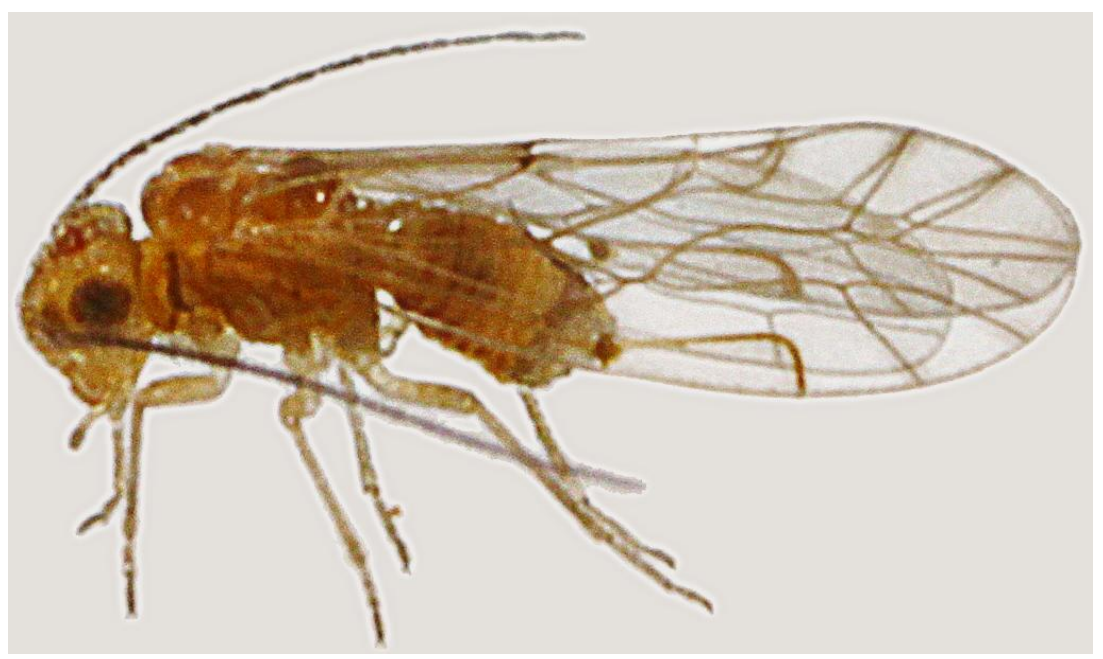

Figure 6. Overall habitus of Lachesilla yucateca Mockford.

\section{Discussion}

Comparison of Mexican and Texas specimens. Females are the same in all characters compared. These include size, body color, forewing shape and markings, form of the ovipositor valvulae, and details of the subgenital plate. In both Texas and Mexican females there is a thin arched line with apex directed forward across the median inner region of the subgenital plate (Figure 5). This was overlooked in the figure of a Mexican female (Mockford, 2002, Fig. 28).

Comparison of Texas males with the single known Mexican male is cut short by the absence of some critical structures in the rather badly mutilated Mexican specimen (see Mockford, 2002, pg. 160 and Figs. 29, 30). Measurements are essentially the same. The only notable difference in measurements is in the first antennal flagellomere, measuring $181 \mu \mathrm{m}$ in the Mexican versus $163 \mu \mathrm{m}$ in both Texas males measured. In the forewing, vein R1 in the distal end of the pterostigma is slightly rounded in the Texas males versus straight in the Mexican male; otherwise, no notable differences in proportions or 
marking of the forewing were noted. The hypandrium of the Mexican male is considerably longer than in the Texas males, but that may result from damage of the Mexican specimen. The phallosomal apodeme is of about the same length and thickness in the two, and is pointed at its base in both. The relative length and the curvature of the phallosomal arms are much greater in the Mexican male than in the Texan males. The epiproctal process of the Mexican male appears to be slightly longer than in the Texas specimens; in both it is acutely pointed at the apex, but in the Texas specimens, the apex is curved to the right, while in the Mexican specimen it is straight. Also, the Texas specimens show a swelling of this structure before the tip, while the Mexican specimen does not. The differences in the phallosomal arms and epiproctal process are real, and cannot be attributed to damage to the Mexican specimen. Comparison of these differences with structures found in other members of the complex (see Mockford, 2002) suggests that the Mexican male may represent a distinct species (no females are known from the locality of this male), but the similarities in other structures argue for this male being the same species. It will be interesting to note variation when other males are found in Mexico.

Range extension of the species. The northernmost record of this species in Mexico is $0.6 \mathrm{~km}$ south of the road to the village Xicotencatl on Highway 85, Tamaulipas State. The distance from that point to the Welder Wildlife Reserve, the southernmost Texas site, almost due north from the Tamaulipas site, is approximately $612 \mathrm{~km}$. Whether or not this presents a real gap in the distribution of the species is a matter of speculation at present. Very little psocid collecting has been done in Tamaulipas State. On the contrary, in Nuevo León, the state immediately west of Tamaulipas, and also bordering Texas in the north, a fair amount of psocid collecting has been done (see Mockford and García Aldrete, 1996), and this species has not been found. This fact suggests the possibility that the gap may be real, at least south of the Mexican border.

\section{Acknowledgments}

We thank the staff of the Welder Wildlife Foundation for lodging and permission to collect at the Welder Wildlife Reserve. We also thank Tom and Janie White of Rockport, Texas for lodging on collecting trips, and two anonymous reviewers for additions and corrections on the original manuscript.

\section{Literature Cited}

García Aldrete, A. N. 1974. A classification above species level of the genus Lachesilla Westwood (Psocoptera: Lachesillidae). Folia Entomológica Mexicana 27: 1 -88.

Mockford, E. L. 1989. Xanthocaecilius (Psocoptera: Caecilliidae), a new genus from the Western Hemisphere: I. Description, species complexes, and species of the quilliyute and granulosus complexes. Transactions of the American Entomological Society 114: 265 - 293.

Mockford, E. L. 2002. Taxonomy of the species of the Lachesilla rena complex (Psocoptera: Lachesillidae). Entomological News 113: 149 - 162.

Mockford, E. L. and García Aldrete, A. N. 1996. Psocoptera. pp. 175 - 205. In, Llorente Bousquets, J., A. N. García Aldrete, and E. González Soriano. (Editors). Biodiversidad, taxonomía y biogeographía de Artrópodos de México: Hacia una síntesis de su conocimiento. Universidad Nacional Autónoma de México. México, Distrito Federal, México. 660 pp. 